which would not affect greatly the clotting time of re-calcified plasma; such a diet is consumed by Jamaicans who are prone to atherosclerosis but not to ischaemic heart disease (Robertson, 1959). On the other hand, increasing the dietary ratio of stearic acid to linoleic acid, as is the tendency in our diets, would tend to increase the coagulability of blood and so make us prone to ischaemic heart disease and pulmonary infarction, deaths from both of which appear to be increasing in this country at about the same rate.

\title{
REFERENCES
}

Ahrens, E. H. Jr., Blankenhorn, D. H. \& Tsaltas, T. T. (1954), Proc. Soc. exp. Biol., N.Y., 86, 872. Ahrens, E. H. Jr., Insull, W. Jr., Hirsch, J., Stoffel, W., Peterson, M. L., Farquhar, J. W., Miller, 'T. \& Thomasson, H. J. (1959). Lancet, i, 115.

Anderson, J. T., Grande, F. \& Keys, A. (1961). Fed. Proc. 20, 96.

Atwater, W. O. \& Bryant, A. P. (1900). Rep. (Storrs) agric. Exp. Sta., I 899.

Bergström, S. (1959). In Hormones and Atherosclerosis. [G. Pincus, editor.] New York: Academic Press Inc.

Evans, H. M. \& Lepkovsky, S. (1929). F. biol. Chem. 83, 269.

Greig, H. B. W. \& Runde, I. A. (1957). Lancet, 273, 46 I.

Groen, J., Tjiong, B. K., Kamminga, C. E. \& Willebrands, A. F. (1952). Voeding, 13, 556.

Hegsted, D. M., Andrus, S. B., Gotsis, A. \& Portman, O. W. (r957). F. Nutr. 63, 273.

Hilditch, T. P. (1956). The Chemical Constitution of Natural Fats, 3 rd ed. London: Chapman \& Hall.

Hollingsworth, D. F., Vaughan, M. C. \& Warnock, G. M. (1957). Proc. Nutr. Sac. 15, xvii.

Keys, A. (1953). Y. Mt. Sinai Hosp. 20, 134.

Keys, A., Anderson, J. T. \& Grande, F. (1957). Lancet, 273, 959.

Kingsbury, K. J., Morgan, D. M. \& Shervington, P. (1960). Lancet, ii, 1045.

Kinsell, L. W., Partridge, J., Boling, L., Margen, S. \& Michaels, G. (I952). F. clin. Endocrin. 12, 909.

Kinsell, L. W. \& Sinclair, H. M. (1957). Lancet, 272, 883.

McCann, M. B. \& Trulson, M. F. (1957). F. Amer. diet. Ass. 33, 358.

McDonald, L. \& Edgill, M. (1959). Lancet, ii, i 1 I 5.

Mead, J. F. (г960). In Lipide Metabolism, Chapter 2. [K. Bloch, editor.] New York: John Wiley \& Sons Inc.

Monkhouse, F. C. (1960). Amer. F. clin. Nutr. 8, I.

Nothman, M. M. \& Proger, S. (196r). Fed. Proc. 20, 90.

Pilkington, T. R. E. (1957). Clin. Sci. x6, 269.

Poole, J. C. F. (1955). Brit. F. exp. Path. 36, 248.

Poole, J. C. F. (1957). In The Lipids and the Clearing Factor, p. 379. Brussels: Palais der Academiën.

Poole, J. C. F. (1958). Brit. med. Bull. r4, no. 3, p. 253.

Poole, J. C. F. (1959). Quart. F. exp. Physiol. 44, 377.

Robertson, W. B. (1959). Lancet, i, 444.

Shorland, F. B. (1950). Nature, Lond., 165, 776.

Silk, M. H. \& Hahn, H. H. (1954). Biochem. F. 57, 582 .

Sinclair, H. M. (1956). Lancet, 270, $3^{81}$.

Sinclair, H. M. (1959). Lancet, i, 474 .

Sinclair, H. M. (196i). F. Atheroscler. Res. r, 8 I.

\section{Hydrogenated oils and polyunsaturated fatty-acid isomers in nutrition}

\section{By E. Aars-Jørgensen, Department of Biochemistry and Nutrition, Polytechnic Institute, Copenhagen}

Hydrogenation is used to change normally liquid oils containing polyenoic fatty acids into semi-solid fats suitable for dietary and manufacturing purposes, e.g. oleomargarine and baking products. Vegetable and marine oils are most commonly used for partial hydrogenations. Vegetable oils contain polyenoic acids of no greater 
unsaturation than the trienoic acid, linolenic acid, which together with linoleic acid are the major polyunsaturated acids in this type of oil. Although the unravelling of the polyunsaturated fatty-acid pattern of marine oils has barely begun it is known that these oils contain only small amounts of essential fatty acids (EFA), but they do contain large quantities of highly unsaturated fatty acids, many of which have carbon chains with more than eighteen carbon atoms.

During recent years new analytical techniques have made possible a better understanding of the chemical reactions underlying the hydrogenation process. The products obtained by partial hydrogenation of an oil vary greatly, depending on the type of oil and no less upon the hydrogenation conditions used, i.e. type of catalyst, its concentration, hydrogen pressure, temperature, and agitation of the mixture during the reaction. Partial hydrogenation of an oil results not only in saturation of some of the double bonds but also in formation of a large number of isomers, geometrical and positional, of the polyenoic fatty acids. Geometrical isomerization and migration of double bonds during partial hydrogenation of oleate was described by Moore (I9I9) and by Hilditch \& Vidyarthi (1929). However, not until recently has renewed interest in this field created a background for the understanding of the reaction mechanisms behind the isomerization processes. Space does not permit an extensive review of this literature.

Hydrogenation is a heterogenous catalysis whereby the double bonds of unsaturated fatty acids are brought into contact with the surface of a catalyst where the reactions take place. Studies by Boelhouwer, Gerckens, Lie \& Waterman (1953), Allen \& Kiess (1955, 1956a, 1956b) and Allen (1956) on isomerization by hydrogenation of monoenoic acids, linoleic acid, linolenic acid, and of conjugated dienoic and trienoic acids resulted in a theory of partial hydrogenation-dehydrogenation as an explanation of the simultaneous formation of both positional and geometrical isomers. Further, Emmet (1959) suggested that at least one of the reactants is chemically adsorbed to the catalyst. Thus, when an unsaturated fatty acid is adsorbed onto the surface of the catalyst, such as nickel powder, chemical bonds are established between the fatty acid and the catalyst, i.e. a double bond is 'opened'. The two free bonds created are attached to two of the nickel atoms. The fatty-acid-catalyst complex then reacts with a hydrogen atom and a semi-hydrogenated product is formed in which the fatty acid is still linked with the catalyst by one bond. At this stage several possibilities are open. If the complex reacts with one more hydrogen atom the original double bond is saturated. Another possibility is that the first adsorbed hydrogen atom can be released whereby the original double bond is re-established. However, desorption of a hydrogen atom can also occur at the carbon atom on the other side of the fatty-acid-catalyst link, then a positional isomer is formed because the double bond is shifted one place relative to its original location. This then explains the formation of conjugated and of isolated double-bond systems. Finally, the semi-hydrogenated fatty-acid-catalyst complex is a system with free rotation around the carbon-carbon link. This situation implies that subsequent removal of a hydrogen atom and desorption from the catalyst will form the double bond at the original location but either in the cis or the trans form. As will be seen, 
this theory apparently explains the formation of positional as well as of geometrical isomers as a result of partial hydrogenation of unsaturated fatty acids. Similar reaction patterns may possibly be followed in enzymically induced transformations of unsaturated fatty acids in vivo.

It is possible to influence the balance between isomerization and hydrogenation to some extent. Hydrogenation of commercial oils is usually carried out under highly selective conditions in which the more unsaturated fatty acids are hydrogenated first. The main factor determining the selectivity and isomer formation in the hydrogenation reaction appears to be the hydrogen concentration in or on the catalyst. Hydrogenation selectivity is low if the catalyst maintains a high concentration of hydrogen which to some extent can be regulated at will by high hydrogen pressure, thereby increasing the speed of the reaction and keeping the formation of trans fatty acids low. A similar effect is obtained by low concentration of the catalyst, fast agitation of the mixture and low reaction temperature. Conversely, low hydrogen concentration on the catalyst due to low hydrogen pressure, slow agitation of the mixture, high reaction temperature, and high catalyst concentration will keep the hydrogenation selectivity high, but unfortunately the rate of formation of isomers is also kept high. The type of catalyst is also of importance for this selectivity. Thus, platinum and palladium catalysts cause more isomerization than a nickel catalyst (Feuge \& Cousins, 1960). Other factors of great importance are catalyst poisons which reduce the effectiveness of the catalyst and consequently change the selectivity and the rate of the reaction. Catalyst poisons are, e.g., sulphur compounds, carbon monoxide or ammonia in the hydrogen gas, or soaps, water, phosphatides and mineral acids in the oils. As an example of the importance of hydrogenation selectivity it can be mentioned that under conditions of high selectivity, linoleic acid reacts about fifty times faster than oleic acid, whereas it reacts only about four times faster in non-selective hydrogenation.

Triglycerides would be expected to behave on hydrogenation like methyl esters, but Feuge, Cousins, Fore, DuPre \& O'Conner (1953), and Feuge, Pepper, O'Conner $\&$ Field (195I) found that under similar operating conditions triglycerides apparently hydrogenated less rapidly than methyl esters, and the amount of trans isomers formed was considerably less. Hydrogenation studies with linoleate (Allen \& Kiess, I $956 a$; Cousins, Guice \& Feuge, I959) showed that not only are some double bonds saturated but others are transformed from cis to trans configuration, the divinylmethane arrangement of the double bonds is changed to conjugated systems, and some of the double bonds are moved along the carbon chain. The effect of operating conditions on migration of double bonds during hydrogenation of cottonseed oil was studied by Chahine, Cousins \& Feuge (1958). They found double bonds in the positions 6-I 4 inclusive of the mono-unsaturated fatty acids resulting from the hydrogenation. They also noticed that even mild conditions of saponification cause some shifting of the double bonds of linoleic acid. Scholfield, Jones, Nowakowska, Selke, Sreenivasan \& Dutton (1960) hydrogenated linolenate and found about $45 \%$ of trans acids to be present in both the monoene and diene fractions. Considerable 
migration of double bonds from the original 9, I2 and I 5 positions occurred, and cis, cis dienes were formed which could not be conjugated by alkali.

It is apparent that partial hydrogenation of an oil or of an unsaturated fatty-acid preparation results in a very complex mixture of fatty acids. Thus, an ordinary pentadiene compound like linoleic acid can form cis and trans forms of no less than nine positional isomeric monoenes. Formation of trans isomers tends to give products that are hard at low temperatures but soft at higher temperatures. Positional isomerization results in increasing melting point by conjugation of the double bonds, whereas a progressive decrease in melting point is observed as the distance between a cis double bond and the carboxyl group increases. With the trans forms no such variations are found.

In general the nutritive value of vegetable oils is high. Thomasson (1953 $a, 1955$, I $956 a$ ) tested the biological value of a large number of fats and oils. He found differences in growth of rats due to a difference in food intake, and a significant correlation between rate of absorption and growth-promoting action of the oils. The decreased rate of absorbability of various oils and fats may perhaps be explained by differences in their fatty-acid composition. The high content of erucic acid, a $\mathrm{C}_{22}$ monoenoic acid, in rapeseed oil may thus account for the slow digestion of this fat.

Marine oils, such as whale, herring, seal, menhaden and tuna oil, support good growth in rats (Thomasson, I953a,b; Aaes-Jørgensen, 1954; Thomasson \& Gottenbos, I 957 ; Privett, Aaes-Jørgensen, Holman \& Lundberg, I959; Ahrens, Insull, Hirsch, Stoffel, Peterson, Farquhar, Miller \& Thomasson, 1959; Privett, Pusch, Holman \& Lundberg, I 960). Regarding the content of EFA in these oils, Privett et al. (I960) concluded that tuna, menhaden and herring oils contain about $2 \%$ of acids belonging to the linoleate family. It is in this connexion interesting to note that Privett et al. (1959) found no relief of the dermal symptoms in EFA-deficient rats by supplementation with the polyunsaturated acid esters (600 mg/animal week) from tuna oil, whereas the $\mathrm{C}_{18}, \mathrm{C}_{20}$ and $\mathrm{C}_{22}$ polyenoic-acid esters stimulated growth. The latter result agrees well with the fact that data from many laboratories (e.g. Thomasson, I956b; Klenk, I958; Klenk \& Debuch, 1959) indicate that the major part of the polyenoic acids from marine oils belong to the linolenic-acid family. Acids of this type are known to support growth but do not relieve or prevent the characteristic dermal signs of EFA deficiency.

It is obvious that partial hydrogenation of marine oils will further reduce the original low content of EFA. 'Therefore, hydrogenated marine oils should only be incorporated into dietary products mixed with oils or fats of a high EFA content, or EFA should be otherwise provided. Partial hydrogenation of vegetable oils is usually less risky from this point of view because of their larger initial content of EFA. An example of the presence of polyenoic-acid isomers in dietary fat was furnished by the examination of typical American margarines and shortenings by Mabrouk \& Brown (1956). They found a mean content of trans acids of about $30 \%$, besides a large number of positional isomers, especially as conjugated fatty acids. The nutritive value of hydrogenated oils has been studied in several different laboratories, often with rather conflicting results. A discussion in detail of this matter is not possible 
here, but a few more general considerations can be made. Unsaturated fatty acids occur in triglycerides, phosphatides, phosphatidic acids, lipoproteins, proteolipids, esters with steroids and the like, they are present in biological membranes, enzyme systems, and interphases, and take part in vital physiological processes. With this background, a possible relationship has been suggested between the presence of isomers in partially hydrogenated oils and the accentuation of EFA deficiency observed when such oils are given as the sole dietary fat to experimental animals (Aaes-Jørgensen, 1954; Aaes-Jørgensen, Funch, Engel \& Dam, 1956; Funch, Aaes-Jørgensen \& Dam, 1957). It may be in favour of such a theory that hydrogenated marine oils accentuate EFA deficiency more than hydrogenated vegetable oils (Aaes-Jørgensen, 1954). However, Burr (1942), Deuel, Greenberg, Anisfeld \& Melnick (195I), and later Peifer \& Holman (1959) suggested that the growthdepressing effect of dietary hydrogenated oils could be explained by an increased demand for EFA with increasing amounts of saturated fat in the diet. Thomasson \& Gottenbos (1957) concluded that the cause of the changes in growth effect due to hardening of oils is related to the increase in content of saturated fatty acids and to the presence of fatty acids with twenty or more carbon atoms. A somewhat similar explanation was suggested by Funch et al. (1957) from experiments with trilaurin or hydrogenated arachis oil as dietary fat.

It should be emphasized that, in animals on diets containing hydrogenated oils, supplementation with adequate amounts of EFA overcomes the growth retardation and prevents the development of the dermal symptoms (Funch et al. 1957; Funch, Jart \& Dam, I960; Thomasson \& Gottenbos, 1957). The last authors obtained an even better growth response with such supplementation than with the original oils.

Another way of studying the nutritive effect of unsaturated fatty-acid isomers is by incorporation, in otherwise fat-free diets, of oils rich in one or more of these isomers, or of isolated isomers. Miller \& Burr (1937) gave tung oil to mature rats and found that elaeostearic acid was converted into dienoic acid. Reiser (I95I) fed laying hens on a diet with conjugated trilinolein or tung oil. Conjugated linoleate appeared in the egg, primarily in the phospholipids, whereas $\alpha$-elaeostearin appeared most prominently in the neutral fat along with large quantities of newly synthesized dienoic acid. Christensen, Dam \& Engel (1957) fed young rats on a diet with $28 \%$ hydrogenated arachis oil containing less than $0.1 \%$ of conjugated dienoic acids. The content of conjugated dienoic acid in the subcutaneous tissue increased to a maximum of about $2 \%$. This maximum coincided with growth retardation of the rats. They suggested that this retardation may have been due to an unfavourable effect of the conjugated acids as such, or of a high dietary content of fat without EFA. Recently, Kaufmann \& Dransfeld (I960) studied the absorption and distribution in the tissues of the seed oil of Impatiens glanduligera which contains parinaric acid (a $\mathrm{C}_{18}$ conjugated tetraenoic acid). The oil was found to be non-toxic to rats and rabbits. When the oil was administered as a single dose, parinaric acid appeared first in the mesenteric, then in the perirenal and last in the subcutaneous and perigenital fatty tissues. The order of appearance of parinaric acid was reversed, as was the turn-over rate, when the oil was given for longer periods of time, 
The nutritive effect of purified conjugated linoleate and of the trans isomers, linolelaidate and elaidolinolenate, on EFA-deficient rats was studied by Holman (195I). Conjugated linoleic acid intensified the deficiency signs. The trans isomers were inactive as EFA. The primary product of linoleate oxidation is found to be a hydroperoxide with conjugated double bonds (Bolland \& Koch, 1945; Privett, Lundberg, Khan, Tolberg \& Wheeler, 1953). Holman \& Greenberg (I954) gave linoleate peroxide, reduced linoleate peroxide, decomposed linoleate peroxide, and conjugated linoleate to EFA-deficient rats. None of these compounds stimulated arachidonate synthesis, the dermal signs were accentuated, growth rate was decreased, and water consumption remained high. They concluded that these compounds containing conjugated double-bond systems exhibit a toxic effect. Upon feeding weanling rats with conjugated isomers or dienoic and trienoic acids for 17 weeks, Aaes-Jørgensen (1958) found no significant adverse effects on growth rate or on the development of dermal signs. Examination of the polyenoic fatty-acid pattern in various tissues revealed that in general only the content of conjugated dienoic acids was affected markedly by the dietary supplementation. They occurred in large amounts in the depot fat, and conjugated cis, trans-linoleate and to a lesser degree ethyl- $\alpha$-elaeostearate increased the content of conjugated dienes in the lipids of the heart. Apparently very little, if any, of the conjugated compounds was deposited in the lipids of testes or brain. It was concluded that the small amounts of conjugated polyenoic acids usually present in hydrogenated oils do not explain the dietary effects observed in experiments with such oils as the sole dietary fat.

Allen, Kiess, Johnston \& Kummerow (1958) fed rats for 16 days on a diet with synthetic triglycerides containing acids with the trans bond in the 9 or 8 position. They found the trans acids to be efficiently metabolized. This finding was further supported by Johnston, Johnson \& Kummerow (1958) who found trans acids to be deposited in the tissues only when they were present in the diet. The largest amounts were found in the carcass fat, smaller amounts in the liver, and only small quantities were excreted in the faeces; the major portion of the ingested trans acids was metabolized. Removal of the trans acids from the diet resulted in gradually decreased amounts in the tissues. Dietary trans fatty acids did not inhibit growth when added to a diet which contained $2 \%$ of soya-bean oil as an EFA source. As mentioned by Johnston et al. (1958), the discrepancy between their results and those of Holman \& Aaes-Jørgensen (1956) may very well be due to the fact that the latter authors were carrying out a curative experiment by supplementing the diet of severely EFA-deficient rats.

In studies by Privett, Pusch \& Holman (1955) the cis-9,trans-12-isomer of linoleate was found not to have EFA activity and no 'sparking' effect on the utilization of linolenate. Trans double bonds derived from the isomer were retained by the animals and deposited in the tissue. Recently Mattson (1960) depleted rats of EFA and then conducted curative experiments by supplementing their diet with 50 or $100 \mathrm{mg} /$ day of linoleate, cis,trans- or trans,trans-linoleate, oleate or elaidate, respectively, for 4 weeks. Dermal signs were not reported. On the basis of gain in bodyweight during this rather short period of supplementation it was concluded that the 
various isomers did not interfere with the utilization of cis,cis-linoleate or increase the requirement for EFA. Further, spermatogenesis was normal in the EFA-deficient animals. This latter statement is not surprising since interference with spermatogenesis occurs only after long periods of EFA depletion. Further, even very small amounts of EFA can delay or abolish this impairment (Aaes-Jørgensen et al. 1956; Funch et al. 1957).

Several experiments seem to indicate that monoenoic trans acids apparently are treated in the organism as ordinary fatty acids (Alfin-Slater, Aftergood, Bingemann, Kryder \& Deuel, 1957; Thomasson \& Gottenbos, 1957), which may not be surprising as it is known that the organism can synthesize various monoenoic acids. Further, trans isomerization by intestinal bacteria occurs in ruminants as well as in non-ruminants (Hartman, Shorland \& Cleverley, I958). However, it has been shown in rats that trans fatty acids behave differently in at least one respect, namely trans fatty acids are not transferred from mother to foetus, but the amount of trans acids increases markedly when the young are allowed to suckle mothers on a diet rich in this type of acid (Johnston, Johnson \& Kummerow, 1957). A similar picture was seen in human beings (Johnston, Kummerow \& Walton, 1958).

It is apparent that several questions regarding the nutritive value of hydrogenated oils are still open for discussion. Some confusion has occurred because occasionally experiments have been compared without enough attention being paid to the fact that some were done with normal and others with EFA-depleted animals. Further, so many isomers are involved that the specific character of those used in the experiments to be compared should be kept in mind. As mentioned above, several reports indicate that hydrogenated oils given as the sole dietary fat have a much poorer nutritive effect than the same oils ordinarily refined, and even markedly poorer than a fat-free diet. A suggested explanation, besides EFA deficiency, is that the increased content of saturated fatty acids formed by hydrogenation in turn may further increase the demand for EFA. However, a biochemical basis for this suggestion is still lacking.

\section{REFERENCES}

Aaes-Jørgensen, E. (1954). The Role of Fat in the Diet of Rats. 6. Influence on Growth of Various Fats in Ordinary Refined State and after Hydrogenation or Polymerization. Copenhagen: Store Nordiske Videnskabsboghandel.

Aaes-Jørgensen, E. (1958). F. Nutr. 66, 465.

Aaes-Jørgensen, E., Funch, J. P., Engel, P. F. \& Dam, H. (1956). Brit. F. Nutr. 10, 292.

Ahrens, E. H. Jr., Insull, W. Jr., Hitsch, J., Stoffel, W., Peterson, M. L., Farquhar, J. W., Miller, 'Г. \& Thomasson, H. J. (I959). Lancet, i, II 5 .

Alfin-Slater, R. B., Aftergood, L., Bingemann, L., Kryder, G. D. \& Deuel, H. J. Jr. (I957). Proc. Soc. exp. Biol., N.Y., 95, 521 .

Allen, R. R. (1956). भ. Amer. Oil Chem. Soc. 33, 301 .

Allen, R. R. \& Kiess, A. A. (r955). F. Amer. Oil Chem. Soc. 32, 400.

Allen, R. R. \& Kiess, A. A. (r956a). F. Amer. Oil Chem. Soc. 33, 355.

Allen, R. R. \& Kiess, A. A. (1956b). F. Amer. Oil Chem. Soc. 33, 419.

Allen, R. R., Kiess, A. A., Johnston, P. V. \& Kummerow, F. A. (1958). F. Amer. Oil Chem. Soc. 35, 203. Boelhouwer, C., Gerckens, J., Lie, O. T. \& Waterman, H. I. (r953). F. Amer. Oil Chem. Soc. 30, 59. Bolland, J. L. \& Koch, H. P. (1945). F. chem. Soc. p. 445.

Burr, G. O. (1942). Fed. Proc. I, 224.

Chahine, M. H., Cousins, E. R. \& Feuge, R. O. (1958). F. Amer. Oil Chem. Soc. 35, 396.

Christensen, F., Dam, H. \& Engel, P. F. (1957). Acta physiol. scand. 38, 373. 
Cousins, E. R. Guice, W. A. \& Feuge, R. O. (1959). F. Amer. Oil Chem. Soc. 36, 24.

Deuel, H. J. Jr., Greenberg, S. M., Anisfeld, L. \& Melnick, D. (1951). F. Nutr. 45, 535.

Emmet, P. H. (1959). F. phys. Chem. 63, 449.

Feuge, R. O. \& Cousins, E. R. (I 960). F. Amer. Oil Chem. Soc. 37, 267.

Feuge, R. O., Cousins, E. R., Fore, S. P., DuPre, E. F. \& O'Conner, R. T. (1953). f. Amer. Oil Chem. Soc. 30, 454 .

Feuge, R. O., Pepper, M. B. Jr., O’Conner, R. T. \& Field, E. T. (I951). Y. Amer. Oil Chem. Soc. 28, 420 .

Funch, J. P., Aaes-Jørgensen, E. \& Dam, H. (1957). Brit. Y. Nutr. r1, 426 .

Funch, J. P., Jart, A. \& Dam, H. (1960). Brit. F. Nutr. I4, I7I.

Hartman, L., Shorland, F. B. \& Cleverley, B. (1958). Biochem. F. 69, r.

Hilditch, T. P. \& Vidyarthi, N. L. (1929). Proc. roy. Soc. A, 122, 552.

Holman, R. T. (1951). Proc. Soc. exp. Biol., N.Y., 76, 100

Holman, R. T. \& Aaes-Jorgensen, E. (1956). Proc. Soc. exp. Biol., N.Y., 93, 175.

Holman, R. T. \& Greenberg, S. I. (1954). Arch. Biochem. Biophys. 49, 49.

Johnston, P. V., Johnson, O. C. \& Kummerow, F. A. (1957). Proc. Soc. exp. Biol., N.Y., 96, 760.

Johnston, P. V., Johnson, O. C. \& Kummerow, F. A. (1958). F. Nutr. 65, I3.

Johnston, P. V., Kummerow, F. A. \& Walton, C. H. (1958). Proc. Soc. exp. Biol., N.Y., 99, 735.

Kaufmann, H. P. \& Dransfeld, H. (1960). Fette, Seif. u. Anstrichmit. 62, 73.

Klenk, E. (1958). In Essential Fatty Acids, p. 57. [H. M. Sinclair, editor.] London: Butterworths Scientific Publications.

Klenk, E. \& Debuch, H. (1959). Annu. Rev. Biochem. 28, 39.

Mabrouk, A. F. \& Brown, J. B. (1956). F. Amer. Oil Chem. Soc. 33, 98.

Mattson, F. H. (1960). F. Nutr. 71, 366 .

Moore, C. W. (1919). F. Soc. chem. Ind., Lond., 38, 320T.

Miller, E. S. \& Burr, G. O. (1937). Proc. Soc. exp. Biol., N. Y., 36, 726.

Peifer, J. J. \& Holman, R. T. (1959). F. Nutr. 68, I55.

Privett, O. S., Aaes-Jørgensen, E., Holman, R. T. \& Lundberg, W. O. (r959). F. Nutr. 67, 423.

Privett, O. S., Lundberg, W. O., Khan, N. A., Tolberg, W. \& Wheeler, D. J. (1953). F. Amer. Oil Chem. Soc. 30, 61.

Privett, O. S., Pusch, F. J. \& Holman, R. T. (I955). Arch. Biochem. Biophys. 57, I 56.

Privett, O. S., Pusch, F. J., Holman, R. T. \& Lundberg, W. O. (1960). F. Nutr. 71, 66.

Reiser, R. (195I). Arch. Biochem. Biophys. 32, I 3 .

Scholfield, C. R., Jones, E. P., Nowakowska, J., Selke, E., Sreenivasan, B. \& Dutton, H. J. (1960). F. Amer. Oil Chem. Soc. 37, 579 .

Thomasson, H. J. (1953a). Int. Z. Vitaminforsch. 25, 62.

Thomasson, H. J. (1953b). In International Conference on Biochemical Problems of Lipids, p. 212. [R. Ruyssen, editor.] Brussels: Palais der Academiën.

Thomasson, H. J. (1955). F. Nutr. 56, 455 .

Thomasson, H. J. (1956a). F. Nutr. 59, 343 .

Thomasson, H. J. (1956b), In International Conference on Biochemical Problems of Lipids, p. 452. [G. Popják and E. LeBreton, editors.] London: Butterworths Scientific Publications.

Thomasson, H. J. \& Gottenbos, J. J. (1957). Verh. vlaam. Akad. Geneesk. Belg. 19, 369.

\section{Fats and atherosclerosis in fowls}

\section{By W. G. Siller and W. Bolton, Agricultural Research Council Poultry Research Centre, West Mains Road, Edinburgh 9}

The finding that atheromatous plaques contained lipid, and especially cholesterol, prompted research on the production of this disease by addition of this sterol to the diet. Several species of experimental animals have been used; the fowl, being omnivorous and susceptible to spontaneous atherosclerosis, has proved popular for research (Katz \& Stamler, I953).

Kinsell, Partridge, Boling, Margen \& Michaels (1952) and many later workers (cf. van Itallie, 1957) observed that the addition to human diets of vegetable fats, 